\title{
Prolactin administration during the luteal and follicular phase of the oestrous cycle of gilts*
}

\author{
L. Dusza†, J. E. Tilton and R. M. Weigl \\ Department of Animal Science, North Dakota State University, Fargo, North Dakota 58105, U.S.A.
}

\begin{abstract}
Summary. In Exp. I infusions of prolactin $(0.5 \mathrm{mg}$ in $2 \mathrm{ml}$ sterile saline) were repeated every $2 \mathrm{~h}$ for $36 \mathrm{~h}$ on Days $12-13$ of the cycle. In Exp. II infusions of prolactin were administered from Days 17 to $19(60 \mathrm{~h})$ at 2-h intervals. Control gilts were given $2 \mathrm{ml}$ sterile saline at similar intervals during the same period. Basal prolactin concentrations before initiation of infusions ranged from $1 \cdot 3 \pm 0 \cdot 1$ to $5 \cdot 6 \pm 2 \cdot 2 \mathrm{ng} / \mathrm{ml}$ in both experiments. By 5 min after a prolactin infusion, mean plasma prolactin concentration ranged from $74.9 \pm 5.8$ to $113.0 \pm 9.5 \mathrm{ng} / \mathrm{ml}$, but then declined to $\simeq 10 \mathrm{ng} / \mathrm{ml}$ just before the next infusion of prolactin. Administration of prolactin during the luteal phase of the oestrous cycle of the gilts had no effect on basal levels of progesterone, oestradiol or LH. During the follicular phase there were no differences $(P>0.05)$ between control and prolactin-treated gilt progesterone and LH concentrations, but oestradiol plasma values were decreased $(P<0.05)$ on the 2 nd and 3 rd day of prolactin treatment. Our results would indicate that prolactin does not play a major role in the regulation of the oestrous cycle of the pig.
\end{abstract}

\section{Introduction}

Two fairly distinct peaks of prolactin release have been observed during the oestrous cycle of pigs. One occurs 4 days before and the other during sexual receptivity (Brinkley, Wilfinger \& Young, 1973; van Landeghem \& van de Wiel, 1977; Dusza \& Krzymowska, 1979; van de Wiel, Erkens, Vos \& van Landeghem, 1981). Rolland \& Hammond (1975) and Rolland, Gunsalus \& Hammond (1976) demonstrated that there were ovarian receptors which bind prolactin in sows and that their presence was subject to cyclic variation.

Prolactin secretion has been suggested to have a direct involvement at the ovarian level on the development of the follicle and subsequent maintenance of luteal function in some species (McNeilly, Glasier, Jonassen \& Howie, 1982). McNeilly et al. (1982) reported that abnormally high prolactin concentrations were associated with the inhibition of normal ovarian activity. Intramuscular administration of prolactin failed to maintain the corpus luteum in hypophysectomizedhysterectomized gilts (du Mesnil du Buisson, Leglise \& Anderson, 1964).

Studies with porcine ovarian cells in vitro indicated that the effect of prolactin on steroid secretion by cultured cells depended on the presence of the corpus luteum or follicular maturation, as well as the dose of available hormone, with the results sometimes contradictory. Veldhuis, Klase \& Hammond (1980) reported that ovine prolactin produced a dose dependent inhibition of progesterone secretion by cultured granulosa cells isolated from small immature follicles of pig ovaries. However, when the granulosa cells were isolated from large mature follicles, prolactin had an opposite effect upon steroidogenesis, stimulating progesterone secretion. Gregoraszczuk (1983)

*Reprint requests to Dr J. E. Tilton.

†Present address: Institute of Animal Physiology, University of Agriculture and Technology, 10-718 Olsztyn, Poland. 
noted that prolactin stimulated progesterone secretion by luteal cells harvested during the early luteal phase but not from the mid-luteal phase. However, Przala, Grazul \& Wiesak (1984a) suggested an inhibitory effect of prolactin on progesterone secretion by luteal cells isolated on Days 5 and 13, but not on Day 17. Also, the in-vitro observations of Przala, Wiesak, Grazul \& Cieplinska (1984b) suggest a role of prolactin in inhibiting synthesis or release of $5 \alpha$-dihydrotestosterone, testosterone and oestradiol-17 $\beta$ from luteal cells. The effect of prolactin was most pronounced on Day 13 luteal cells.

In earlier work (Dusza et al., 1984), highly purified pig prolactin $(0 \cdot 15 \mathrm{mg})$ was administered every $2 \mathrm{~h}$ to the sows from weaning until the end of first oestrus: only oestradiol concentrations were decreased, LH and progesterone concentrations were similar in the treated and control animals and signs of oestrus occurred in all sows 5-6 days after weaning. The present study was conducted to determine the effect of intravenous infusion of high doses of prolactin on secretory patterns of progesterone, oestradiol and LH during the luteal (Exp. I) and follicular (Exp. II) phases of the oestrous cycle in cyclic gilts.

\section{Materials and Methods}

\section{Animals and experimental design}

Crossbred gilts, 9-10 months of age with normal durations of the oestrous cycle, were assigned to treatment after their second oestrous period. All gilts were exposed once daily to intact yearling boars to determine onset of oestrus. In Exp. I, 12 gilts ( 6 control, Group C; 6 treated, Group T) were bilaterally cannulated on Day 10 of the oestrous cycle (Day $0=$ day of onset of oestrus) through the humeral cephalic vein into the anterior vena cava. One cannula was used for infusions of prolactin (Group T) or saline $(9 \mathrm{~g} \mathrm{NaCl} / 1$; Group C), the other for collection of blood samples. Infusion of $0.5 \mathrm{mg}$ pig prolactin (pPrl-KK-3) in $2 \mathrm{ml}$ saline was begun at 09:00 h on Day 12 and repeated every $2 \mathrm{~h}$ until Day 13 at $21: 00 \mathrm{~h}(36 \mathrm{~h})$. The purified prolactin used had an activity of 30 i.u./mg and was free of porcine $\mathrm{GH}, \mathrm{LH}$ and $\mathrm{FSH}$, as tested by polyacrylamide gel electrophoresis. Control gilts were given $2 \mathrm{ml}$ saline at comparable intervals. Starting $24 \mathrm{~h}$ before prolactin or saline infusions, peripheral blood samples were collected every $6 \mathrm{~h}$. During the period of prolactin administration one plasma sample was taken immediately before the prolactin or saline infusion and a second sample was withdrawn $5 \mathrm{~min}$ after the prolactin or saline treatment. After treatment was terminated 3 samples of blood were taken at 4-h intervals. All blood samples were centrifuged and the plasma was stored in aliquants at $-20^{\circ} \mathrm{C}$ until hormone analysis.

In Exp. II 12 gilts (6 in Group C, 6 in Group T) were bilaterally cannulated on Day 15. Infusions of prolactin $(0.5 \mathrm{mg}$ in $2 \mathrm{ml}$ saline $)$ were administered for $60 \mathrm{~h}$ during the follicular phase of the oestrous cycle. The prolactin or saline infusions were given every $2 \mathrm{~h}$ from 09:00 $\mathrm{h}$ on Day 17 until 20:00 h on Day 19. Blood samples were withdrawn every $6 \mathrm{~h}$ for $24 \mathrm{~h}$ before treatment, immediately before and $5 \mathrm{~min}$ after prolactin or saline infusion with 3 samples of blood taken at 4-h intervals after termination of treatment on Day 19.

\section{Hormone assays}

Plasma prolactin concentrations were determined in duplicate in a specific double-antibody radioimmunoassay as described previously (Dusza \& Krzymowska, 1979). In this assay we used goat anti-porcine prolactin (Research Products, Mt Prospect, IL, U.S.A.). Plasma progesterone, oestradiol and LH were measured as described by Schneider et al. (1983), Williams \& Ray (1980) and Ziecik, Krzymowska \& Tilton (1982), respectively. The sensitivities per assay tube for prolactin, progesterone, oestradiol and $\mathrm{LH}$ were $0.03 \mathrm{ng}, 10 \mathrm{pg}, 2.5 \mathrm{pg}$ and $0.07 \mathrm{ng}$, respectively. Intra- and interassay coefficients of variation for prolactin, progesterone, oestradiol and $\mathrm{LH}$ were 2.9 and $9.8 \%, 5.6$ and $10.0 \%, 2.3$ and $10.0 \%$ and $2 \cdot 8$ and $6.1 \%$, respectively. 
During the periods of prolactin administration, concentrations of plasma progesterone, oestradiol and LH were determined in the blood samples collected $5 \mathrm{~min}$ after hormone or saline infusion and not in the preinfusion samples. Prolactin concentrations were measured immediately before the prolactin or saline infusion and $5 \mathrm{~min}$ after treatment. Results were analysed by analysis of variance.

\section{Results}

During the luteal phase of the oestrous cycle (Exp. I) plasma prolactin concentrations of control gilts oscillated around $2 \mathrm{ng} / \mathrm{ml}$ and were not affected by saline infusions. Administration of

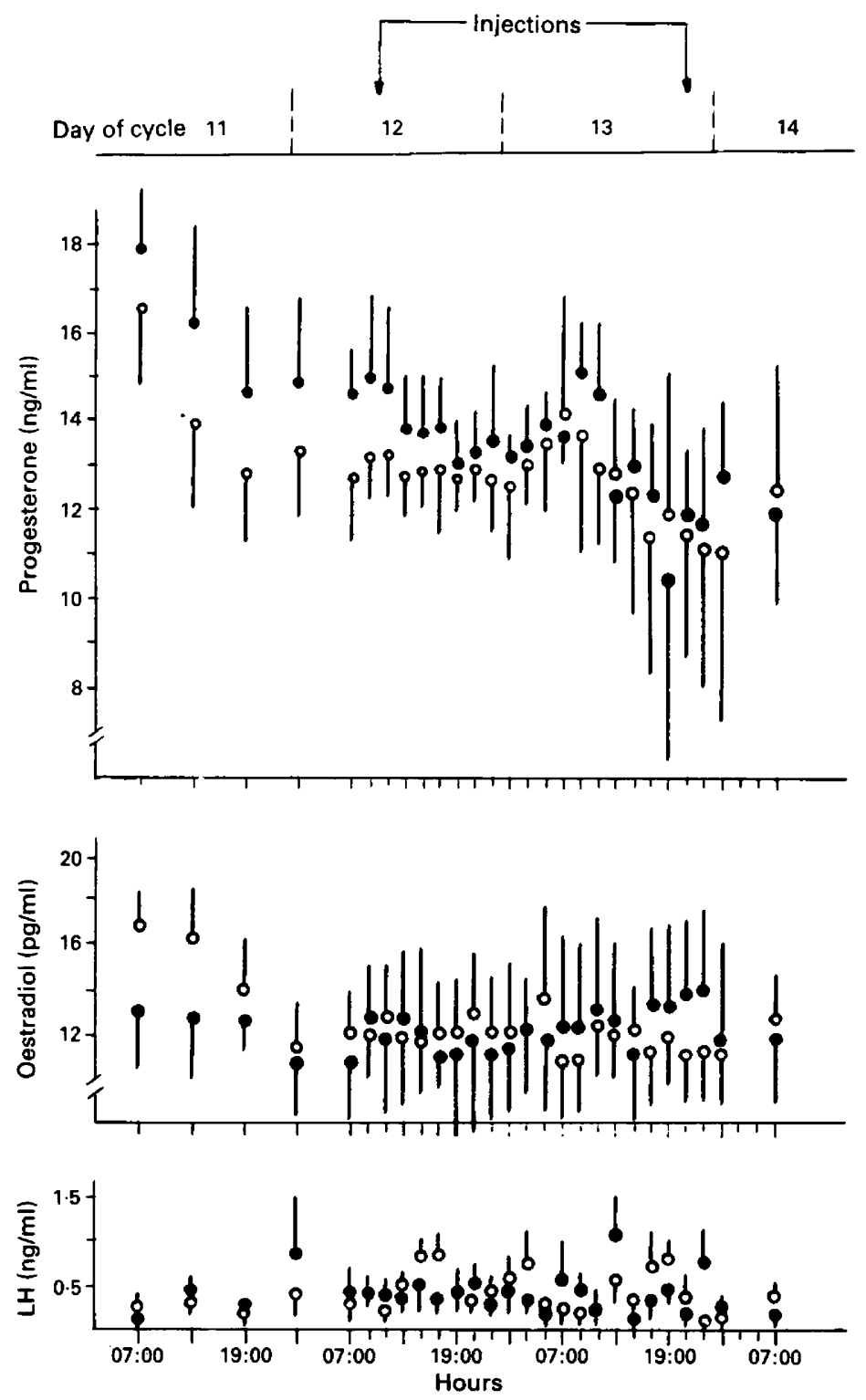

Fig. 1. Mean \pm s.e.m. plasma concentrations of progesterone, oestradiol and LH during the luteal phase (Exp. I) after saline $(\Theta)$ or prolactin $(O)$ infusions. 

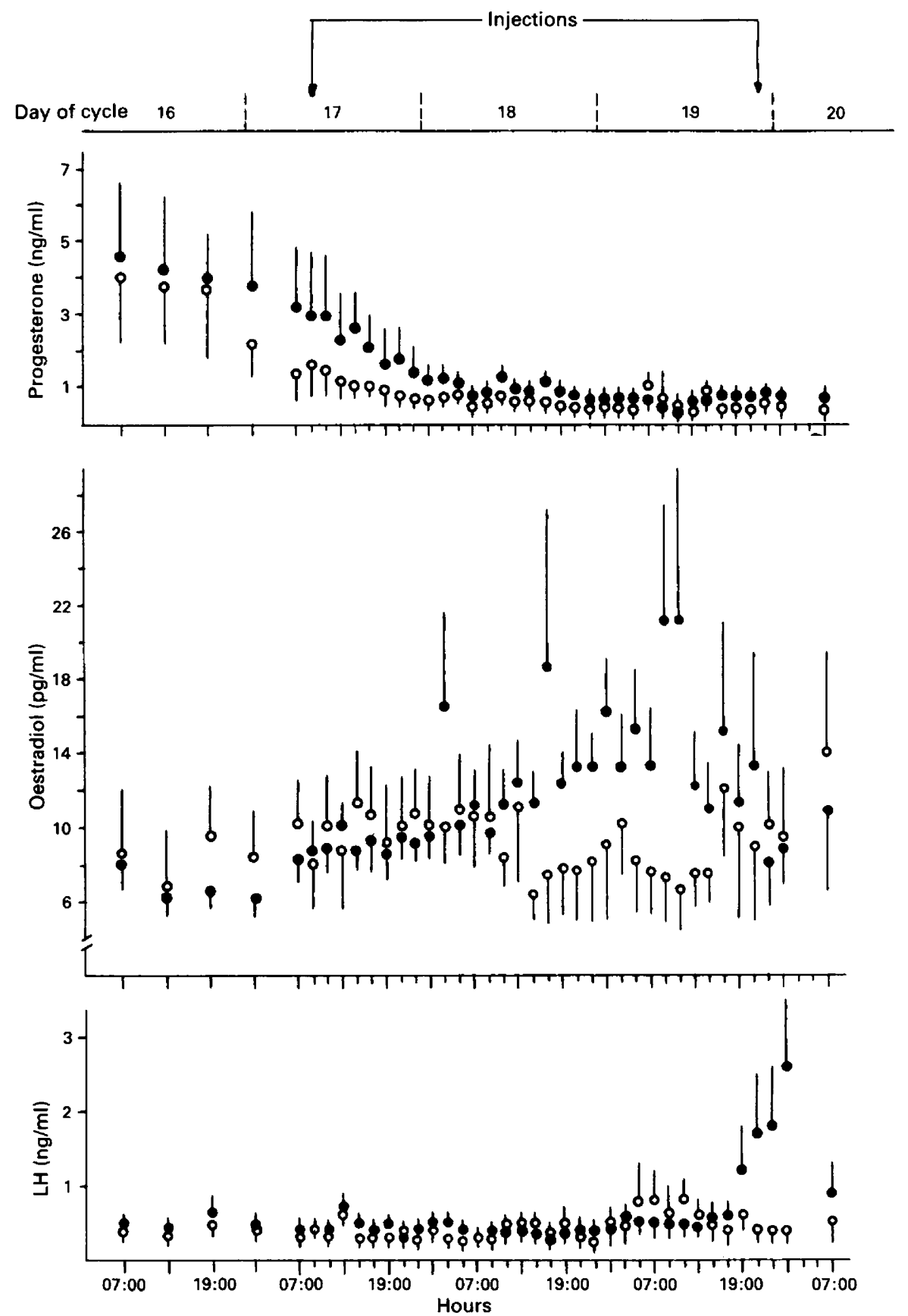

Fig. 2. Mean \pm s.e.m. plasma concentrations of progesterone, oestradiol and LH during the follicular phase (Exp. II) after saline $(O)$ or prolactin $(O)$ infusions.

prolactin caused an acute increase in plasma prolactin concentration to about $100 \pm 11.4 \mathrm{ng} / \mathrm{ml}$ $(P<0.001)$. These concentrations then declined to $\simeq 10 \mathrm{ng} / \mathrm{ml}$ during the 2-h period after infusion. The infusions produced a 5 -fold increase over control plasma concentrations. The administration 
of prolactin on a 2-h schedule during Day 12 and 13 did not alter the secretory patterns of the ovarian steroids or LH (Fig. 1).

In Exp. II basal prolactin concentration before the start of hormone or saline treatments ranged from $2 \cdot 2 \pm 0 \cdot 4$ to $5 \cdot 6 \pm 2 \cdot 2 \mathrm{ng} / \mathrm{ml}$. In the control animals saline infusions did not affect prolactin values $(P>0.05)$. Prolactin treatment elevated circulating prolactin concentrations to values ranging from $74.9 \pm 5.8$ to $104 \pm 13.3 \mathrm{ng} / \mathrm{ml}$. Immediately before the next prolactin infusion, prolactin values were $10 \mathrm{ng} / \mathrm{ml}$.

There were no significant differences in progesterone concentrations between animals in Groups $\mathrm{C}$ and $\mathrm{T}$ (Fig. 2). Plasma concentrations of oestradiol were decreased $(P<0.05)$ after prolactin injections administered from Day 18 at 11:00 h throughout Day 19 until 15:000 h as illustrated in Fig. 2. Before the time of oestrus, LH concentrations were nearly the same in both groups of animals in Exp. II. Mean concentration of LH in the last 5 samples was elevated in control gilts. Two of 6 gilts had a preovulatory LH surge during this period of the experiment.

\section{Discussion}

The results of Exp. I indicate that elevated concentrations of prolactin in treatment gilts did not affect progesterone, oestradiol or LH plasma concentrations during the late luteal phase. Plasma concentrations of progesterone were comparable for the control and treated groups and mimicked concentrations in the peripheral plasma normally observed at this stage of the cycle (Brinkley, 1981; Schneider et al., 1983). Neither luteolytic nor luteotrophic effects of artificial elevations of prolactin were observed. The failure of prolactin to prolong the life-span of CL in hypophysectomizedhysterectomized gilts had been observed by du Mesnil du Buisson et al. (1964) and in intact or hypophysectomized ewes with intact uteri (Karsch et al., 1971). These results are contrary to those observed by Przala et al. (1984a, b), who reported an inhibitory effect of prolactin in vitro on progesterone and oestradiol secretion by luteal cells isolated on Day 13. Any direct comparison of results from in-vivo and in-vitro assays is difficult.

The infusion of relatively large amounts of pig prolactin into intact gilts during the follicular phase caused no significant changes in progesterone and LH values, but concentrations of oestradiol were reduced in most animals. There are considerable data from in-vivo and in-vitro studies on the relationship between prolactin and oestradiol-17 $\beta$ release. Most workers reported a reduction in oestradiol-17 $\beta$ secretion (Wang, Hsueh \& Erickson, 1980; Dorrington \& GoreLangton, 1981; Demura, Ono, Demura, Shizume \& Oouchi, 1982; Uilenbroek, van der Schoot, Den Besten \& Lankhorst, 1982; McNeilly \& Baird, 1983; Tsai-Morris, Ghosh, Hirshfield, Wise \& Brodie, 1983). In our earlier work involving prolactin administration to sows after weaning, a similar tendency for reduced post-treatment concentrations of oestradiol-17 $\beta$ was observed (Dusza et al., 1984). Prolactin probably results in a direct inhibitory influence on ovarian aromatase activity (Tsai-Morris et al., 1983). However, other modes of prolactin action upon granulosa cells have been suggested. Magoffin \& Erickson (1982) reported that high prolactin could decrease thecal androgen production by inhibiting a step distal to cAMP formation and before or at the cholsterol side-chain cleavage step. It may change secretion of non-steroid regulators which in turn modulate steroidogenesis (Channing \& Evans, 1982). These data suggest the existence of a possible inverse relationship between prolactin and oestradiol-17 $\beta$ in pigs.

A suppressive effect of prolactin on LH concentrations has been suggested (Maneckjee, Strinath \& Moudgal, 1976; Marchetti \& Labrie, 1982; Cheung, 1983). Contradictory evidence has been reported (Chamley, 1978; Forrest, Fleeger, Long, Sorensen \& Harms, 1980; Wright, Findlay \& Anderson, 1981; McNeilly \& Baird, 1983). Administration of prolactin from weaning through first oestrus did not produce a change in the LH pattern (Dusza et al., 1984). The results presented in Fig. 2 do not allow us to draw any definite conclusion pertaining to $\mathrm{LH}$ release because it 
could not be statistically confirmed. Based on the data presented in this study, it appears that prolactin does not play a primary role in the regulation of the oestrous cycle of the sow and its function is therefore still unclear.

Published with the approval of the Dean and Director of the North Dakota Agricultural Experiment Station, Journal Article No. 1388.

\section{References}

Brinkley, H.J. (1981) Endocrine signaling and female reproduction. Biol. Reprod. 24, 22-43.

Brinkley, H.J., Wilfinger, W.W. \& Young, E.P. (1973) Plasma Prl in the estrous cycle of the pig. J. Anim. Sci. 37, 303, Abstr.

Chamley, W.A. (1978) Effect of prolactin on the LH response to synthetic $\mathrm{LH}-\mathrm{RH}$ in ovariectomized ewes. J. Reprod. Fert. 52, 301-304.

Channing, C.P. \& Evans, V.W. (1982) Stimulatory effect of ovine prolactin upon cultured porcine granulosa cell secretion of inhibitory activity of oocyte maturation. Endocrinology 111, 1746-1748.

Cheung, C.Y. (1983) Prolactin suppresses luteinizing hormone secretion and pituitary responsiveness to luteinizing hormone-releasing hormone by a direct action at the anterior pituitary. Endocrinology 113, $632-638$.

Demura, R., Ono, M., Demura, H., Shizume, K. \& Oouchi, M. (1982) Prolactin directly inhibits basal as well as gonadotropin-stimulated secretion of progesterone and $17 \beta$-estradiol in the human ovary. $J$. clin. Endocr. Metab. 54, 1246-1250.

Dorrington, J. \& Gore-Langton, R.E. (1981) Prolactin inhibits oestrogen synthesis in the ovary. Nature, Lond. 290, 600-602.

du Mesnil du Buisson, F., Leglise, P.C. \& Anderson, L.L. (1964) Hypophysectomy in pigs. J. Anim. Sci. 23, 1226, Abstr.

Dusza, L. \& Krzymowska, H. (1979) Plasma prolactin concentrations during the oestrous cycle of sows. $J$. Reprod. Fert. 57, 511-514.

Dusza, L., Kotwica, G., Szafranska, B., Ciereszko, R., Milosz, Z., Kotwica, J., Ziecik, A. \& Krzymowska, H. (1984) Wplyw egzogennej Prl na regulacje hormonalna $u$ macior po odsadzenniu prosiat. (Influence of exogenous Prl on hormonal regulation in sows after weaning.) Zesz. probl. Postep. Nauk roln. 309, 95-104.

Forrest, D.W., Fleeger, J.L., Long, C.R., Sorensen, A.M. \& Harms, P.G. (1980) Effect of exogenous prolactin on peripheral luteinizing hormone levels in ovariectomized cows. Biol. Reprod. 22, 197-201.

Gregoraszczuk, E. (1983) Steroid hormone release in cultures of pig corpus luteum and granulosa cells. Effect of LH, hCG, prolactin and oestradiol. Endocrinol. exp. 17, 59-68.

Karsch, F.J., Cook, B., Ellicott, A.T., Foster, D.L., Jackson, G.L. \& Nalbandov, A. V. (1971) Failure of infused prolactin to prolong the life span of the corpus luteum of the ewe. Endocrinology 89, 272-275.

Magoffin, D.A. \& Erickson, G.F. (1982) Prolactin inhibition of luteinizing hormone-stimulated andro- gen synthesis in ovarian interstitial cells cultured in defined medium: Mechanism of action. Endocrinology 111, 2001-2007.

Maneckjee, R., Strinath, B.R. \& Moudgal, N.R. (1976) Prolactin suppresses release of luteinizing hormone during lactation in the monkey. Nature, Lond. 262, 507-508.

Marchetti, B. \& Labrie, F. (1982) Prolactin inhibits pituitary luteinizing hormone-releasing hormone receptors in the rat. Endocrinology 111, 1209-1216.

McNeilly, A.S. \& Baird, D.T. (1983) Direct effect of prolactin, induced by TRH injection on ovarian oestradiol secretion in the ewe. J. Reprod. Fert. 69, 559-568.

McNeilly, A.S., Glasier, A., Jonassen, J. \& Howie, P.W. (1982) Evidence for direct inhibition of ovarian function by prolactin. J. Reprod. Fert. 65, 559-569.

Przala, J., Grazul, A. \& Wiesak, T. (1984a) The influence of prolactin on progesterone secretion by porcine luteal cells in vitro. Anim. Reprod. Sci. 7, 351-362.

Przala, J., Wiesak, T., Grazul, A. \& Cieplinska, E. (1984b) The effect of prolactin on estradiol-17 $\beta$ and testosterone plus $5 \alpha$-dihydrotestosterone secretion by porcine luteal cells in vitro. Exp. clin. Endocrinol. 83, 343-348.

Rolland, R. \& Hammond, J.M. (1975) Demonstration of a specific receptor for prolactin in porcine granulosa cells. Endocrine Res. Commun. 2, 281-298.

Rolland, R., Gunsalus, G.L. \& Hammond, J.M. (1976) Demonstration of specific binding of prolactin by porcine corpora lutea. Endocrinology 98, 1083-1091.

Schneider, T.M., Tilton, J.E., Okrasa, S., Mah, J., Weigl, R.M. \& Williams, G.L. (1983) The effect of intrauterine infusion of prostaglandin $E_{2}$ on luteal function in nonpregnant gilts. Theriogenology 20, 509-520.

Tsai-Morris, C.H., Ghosh, M., Hirshfield, A.N., Wise, P.M. \& Brodie, A.M.H. (1983) Inhibition of ovarian aromatase by prolactin in vivo. Biol. Reprod. 29, $342-346$.

Uilenbroek, J.Th.J., van der Schoot, P., Den Besten, D. \& Lankhorst, R.R. (1982) A possible direct effect of prolactin on follicular activity. Biol. Reprod. 27, $1119-1125$.

van de Wiel, D.F.M., Erkens, J., Vos, E. \& van Landegham, A.A.J. (1981) Periestrous and midluteal time courses of circulating LH, FSH, prolactin, estradiol-17 $\beta$ and progesterone in the domestic pig. Biol. Reprod. 24, 223-233.

van Landeghem, A.A.J. \& van de Wiel, D.F.M. (1977) Plasma prolactin levels in gilts during the oestrous cycle and at hourly intervals around the time of 
oestrus. Acta endocr., Copenh., Suppl. 212, 143, Abstr.

Veldhuis, J.D., Klase, P. \& Hammond, J.M. (1980) Divergent effects of prolactin upon steroidogenesis by porcine granulosa cells in vitro. Influence of cytodifferentiation. Endocrinology 107, 42-46.

Wang, C., Hsueh, A.J.W. \& Erickson, G.F. (1980) Prolactin inhibition of estrogen production by cultured rat granulosa cells. Molec. cell. Endocrinol. 20, 135-144.

Williams, G.L. \& Ray, D.E. (1980) Hormonal and reproductive profiles of early postpartum beef heifers after prolactin suppression or steroid induced luteal function. J. Anim. Sci. 50, 906-917.

Wright, P.J., Findlay, J.K. \& Anderson, A. (1981) The failure of prolactin to enhance the inhibitory effect of oestradiol-17 $\beta$ on LH synthesis and release in ewes. $J$. Reprod. Fert. 62, 537-542.

Ziecik, A., Krzymowska, H. \& Tilton, J.E. (1982) Porcine LH levels during the estrous cycle, gestation, parturition and early lactation. J. Anim. Sci. 54, 1221-1226.

Received 19 March 1985 